Keywords: $H T O$, deposition velocity, re-emission, Tritium, atmospheric dispersion

Retention: Permanent

\title{
Recommended Tritium Oxide Deposition Velocity for Use in Savannah River Site Safety Analyses
}

C. E. Murphy, P. L. Lee, B. J. Viner and C. H. Hunter

April 3, 2012

Savannah River National Laboratory Savannah River Nuclear Solutions, LLC Aiken, SC 29808
Prepared for the U.S. Department of Energy under contract number DE-AC09-08SR22470. 


\section{DISCLAIMER}

This work was prepared under an agreement with and funded by the U.S. Government. Neither the U.S. Government or its employees, nor any of its contractors, subcontractors or their employees, makes any express or implied:

1. warranty or assumes any legal liability for the accuracy, completeness, or for the use or results of such use of any information, product, or process disclosed; or

2. representation that such use or results of such use would not infringe privately owned rights; or

3. endorsement or recommendation of any specifically identified commercial product, process, or service.

Any views and opinions of authors expressed in this work do not necessarily state or reflect those of the United States Government, or its contractors, or subcontractors.

\section{Printed in the United States of America}

Prepared for

U.S. Department of Energy 


\section{REVIEWS AND APPROVALS}

AUTHORS:

C. E. Murphy, Environmental Sciences Group

Date

P. L. Lee, Manager, Applied Computational Engineering \& Sciences

Date

B. J. Viner, Atmospheric Technologies Group

Date

C. H. Hunter, Manager, Atmospheric Technologies Group

Date

TECHNICAL REVIEWER:

G. T. Jannik, Environmental Sciences Group

Date

APPROVALS:

J. J. Mayer, Manager, Environmental Sciences Group

Date 


\section{PREFACE}

In August 2011, the Defense Nuclear Safety Board Staff (DNFSB) stated the "...dry deposition velocity for tritium oxide $(0.5 \mathrm{~cm} / \mathrm{s})$ recommended in the MACCS2 Computer Code Application Guidance for Documented Safety Analysis Final Report and used in consequence analysis for the tritium facilities does not yield the bounding consequence" in a letter to the U.S. Department of Energy (DOE) National Nuclear Security Administration (NNSA) Administrator. The DNFSB Staff Issue Report issued in March 2011 that requests technical justification for the appropriateness of the deposition velocity being used for the bounding accident scenario and identifies reemission of tritium back into the atmosphere, as a phenomenon that must be reflected in the derivation of an appropriate deposition velocity.

In response to the DNFSB inquiry, Tritium Engineering requested that Savannah River National Laboratory (SRNL) determine and document a technical basis for a Savannah River Site (SRS)-specific tritium oxide (HTO) dry deposition velocity value that is appropriate for use in a bounding accident scenario at SRS Nuclear Facilities. In response to this request, environmental transport and dosimetry subject matter experts at SRNL were consulted to address the technical concerns cited by the DNFSB. As part of the investigation, SRNL hired Dr. Charles Murphy; a retiree of 30 years who has authored several publications on this topic (including site-specific evaluations) and is familiar with the historical worldwide research to assist in this technical evaluation.

This report documents the results of examining the deposition velocity of water to forests, the residence time of HTO in forests, and the relation between deposition velocity and residence time with specific consideration given to the topography and experimental work performed at SRS. A simple mechanistic model is used to obtain plausible deposition velocity and residence time values where experimental data are not available and recommendations are made for practical application in a safety analysis model. 


\section{EXECUTIVE SUMMARY}

The Defense Nuclear Facilities Safety Board (DNFSB) has recently questioned the appropriate value for tritium deposition velocity used in the MELCOR Accident Consequence Code System Ver. 2 (Chanin and Young 1998) code when estimating bounding dose $\left(95^{\text {th }}\right.$ percentile) for safety analysis (DNFSB 2011). The purpose of this paper is to provide appropriate, defensible values of the tritium deposition velocity for use in Savannah River Site (SRS) safety analyses. To accomplish this, consideration must be given to the re-emission of tritium after deposition.

Approximately $85 \%$ of the surface area of the SRS is forested. The majority of the forests are pine plantations, $68 \%$. The remaining forest area is $6 \%$ mixed pine and hardwood and $26 \%$ swamp hardwood. Most of the path from potential release points to the site boundary is through forested land.

A search of published studies indicate daylight, tritiated water (HTO) vapor deposition velocities in forest vegetation can range from 0.07 to $2.8 \mathrm{~cm} / \mathrm{s}$. Analysis of the results of studies done on an SRS pine plantation and climatological data from the SRS meteorological network indicate that the average deposition velocity during daylight periods is around $0.42 \mathrm{~cm} / \mathrm{s}$. The minimum deposition velocity was determined to be about $0.1 \mathrm{~cm} / \mathrm{s}$, which is the recommended bounding value.

Deposition velocity and residence time (half-life) of HTO in vegetation are related by the leaf area and leaf water volume in the forest. For the characteristics of the pine plantation at SRS the residence time corresponding to the average, daylight deposition velocity is 0.4 hours. The residence time corresponding to the night-time deposition velocity of 0.1 $\mathrm{cm} / \mathrm{s}$ is around 2 hours.

A simple dispersion model which accounts for deposition and re-emission of HTO vapor was used to evaluate the impact on exposure to the maximally exposed offsite individual (MOI) at the SRS boundary (Viner 2012). Under conditions that produce the bounding, $95^{\text {th }}$ percentile MOI exposure, i.e., low wind speed, weak turbulence, night, low deposition velocity, the effect of deposition and re-emission on MOI exposure was found to be very small. The exposure over the two hour period following arrival of the plume was found to be decreased by less than $0.05 \%$. Furthermore the sensitivity to deposition velocity was low. Increasing deposition velocity to $0.5 \mathrm{~cm} / \mathrm{s}$ reduced exposure to $0.3 \%$. After a 24 hour period, an MOI would have been exposed to all of the released material. Based on the low sensitivity of MOI exposure to the value of deposition velocity when re-emission is considered, it is appropriately conservative to use a $0.0 \mathrm{~cm} / \mathrm{s}$ effective deposition velocity for safety analysis in the MACCS2 code. 


\section{TABLE OF CONTENTS}

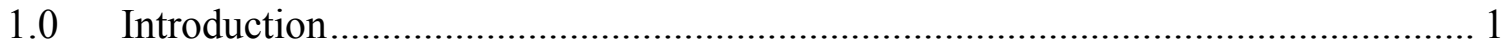

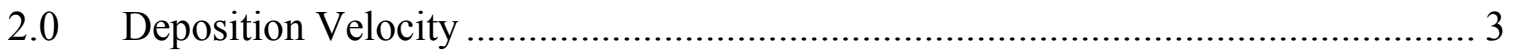

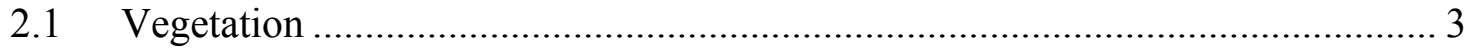

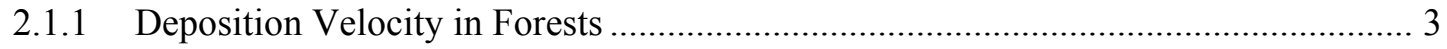

2.1.2 Calculation of Deposition Velocity in an SRS Pine Plantation ................................... 4

2.1.3 Calculation of Deposition Velocity for SRS Forests Considering Hardwood Stands. 5

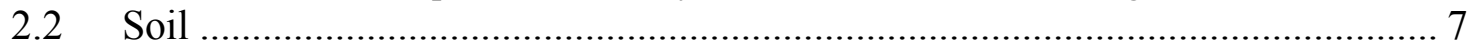

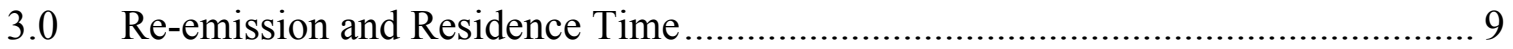

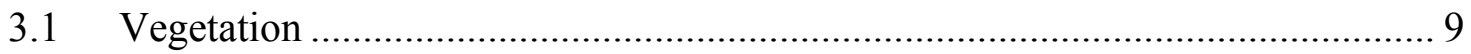

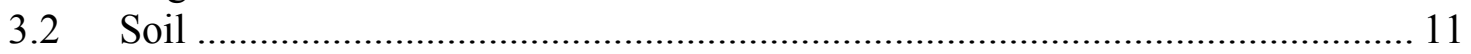

4.0 Modeling of HTO deposition velocity and re-mission in SRS Safety Analyses ... 13

4.1 Deposition Velocity and Re-Emission Model............................................... 13

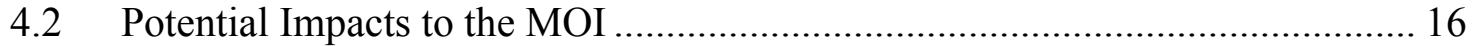

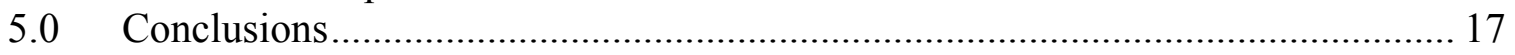

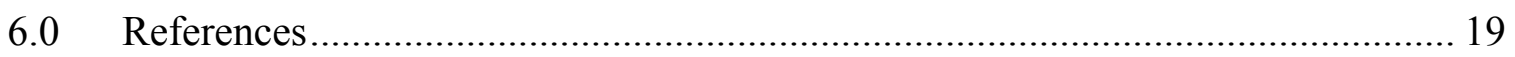




\section{LIST OF TABLES}

Table 1. Published measurements of leaf conductance for forest vegetation................. 3

Table 2. Published measurements of forest deposition velocities ............................... 4

Table 3. Residence time (half-life) of HTO in the forest canopy .............................. 10

Table 4. Residence times for HTO in forest soils.................................................. 11

Table 5. The percent of a puff release of HTO that passes the site boundary $(\sim 11.5 \mathrm{~km})$ within 2 hours of first reaching it................................................................... 15

Table 6. The percent of a puff release of HTO at 100 meters downwind of the release point within 2 hours of first reach that distance..................................................... 16

\section{LIST OF FIGURES}

Figure 1. The network of resistances to HTO vapor transport in a forest. ....................... 2

Figure 2. The frequency distribution of deposition velocity predicted for 15-min meteorology over a year.

Figure 3. Mean deposition velocity of SRS pine forest for Pasquill-Gifford stability classes.

Figure 4. Relationship between residence time and deposition velocity calculated from the surface area and volume of leaf water from a typical pine plantation and mixed hardwood forest.

Figure 5. A cross-section along the center-line of the HTO cloud two hours after first reaching the site boundary (labeled; $11.5 \mathrm{~km}$ ) 


\subsection{INTRODUCTION}

The DNFSB has recently questioned the basis for a Savannah River Site(SRS)-specific value for tritium deposition velocity of 0.5 centimeter per second $(\mathrm{cm} / \mathrm{s})$ currently used in the MELCOR Accident Consequence Code System Ver. 2 (Chanin and Young 1998) (MACCS2) dosimetry code when estimating bounding dose $\left(95^{\text {th }}\right.$ percentile) (DNFSB 2011). The purpose of this paper will be to provide appropriate, defensible values of the deposition velocity for use in SRS safety analyses.

Deposition velocity is defined as the proportionality constant relating air concentration to the flux density of material deposited under a puff or plume release. When dealing with large particles, the deposition velocity is dominated by the gravity-driven terminal velocity of the particles. Deposition of gases and vapors to the forest below a puff or plume is controlled by atmospheric diffusion and the absorption properties of the material on the surface of soil and vegetation.

In this document the deposition and cycling of HTO either as vapor in air or liquid in vegetation is addressed. It is assumed that the bounding condition in safety analysis is for tritium in the form of water. Other forms of tritium are either rare in the scenarios used for safety analysis or have lower dose consequences. Therefore, it is likely that if HTO releases are analyzed they will bound the upper safety consequences of actual, potential releases.

Deposition of HTO vapor is complicated by the relatively rapid re-emission of tritium from the surface once the plume passes. Most of the vapor diffusing into a stand of vegetation will dissolve in water in the leaves. A small fraction of the HTO vapor will reach the soil below the vegetation and dissolve in the soil water. Deposition will stop as equilibrium is reached between the concentration in the air and that in the leaf or soil water. After plume passage, the HTO will diffuse back as vapor into the atmosphere. The residence time of HTO in the leaves of vegetation is relatively short while HTO entering the soil water can be sequestered in the system and have a longer residence time. The significance of re-emission will be evaluated as it is affected by residence time.

The deposition velocity estimates will be developed for SRS vegetation and climate. The SRS consists of 310 square miles of land in the piedmont and coastal plain of South Carolina. The US Forest Service manages $85 \%$ of the land area under an interagency agreement with the US Department of Energy (DOE). The remaining $15 \%$ of the area is roads or production and administrative areas. The forested area is $68 \%$ pine plantations, $6 \%$ is mixed hardwood and pine forest, and $26 \%$ hardwood forest, predominately cypress/tupelo swamp forest.

Meteorological data used in the analyses, consisting of air temperature, relative humidity, and solar radiation, comes from a continuous record of quality assured 15-minute data collected at the SRS Central Climatology tower near N-area during 2010. This facility is located in an open grass-covered field to ensure the measurements are representative of ambient conditions. The temperature and relative humidity sensors are mounted at a height of 2-meters above ground. Solar radiation is measured nearby at ground level. 
In the following sections a look is taken at the deposition velocity of water to forests, the residence time of HTO in forests, and the relation between deposition velocity and residence time. Where ever possible published experimental data are used in the analysis. Where this is not possible a simple resistance model, illustrated in Figure 1, is used to obtain values of deposition velocity and residence time of HTO in forests (Sinclair et al. 1976).

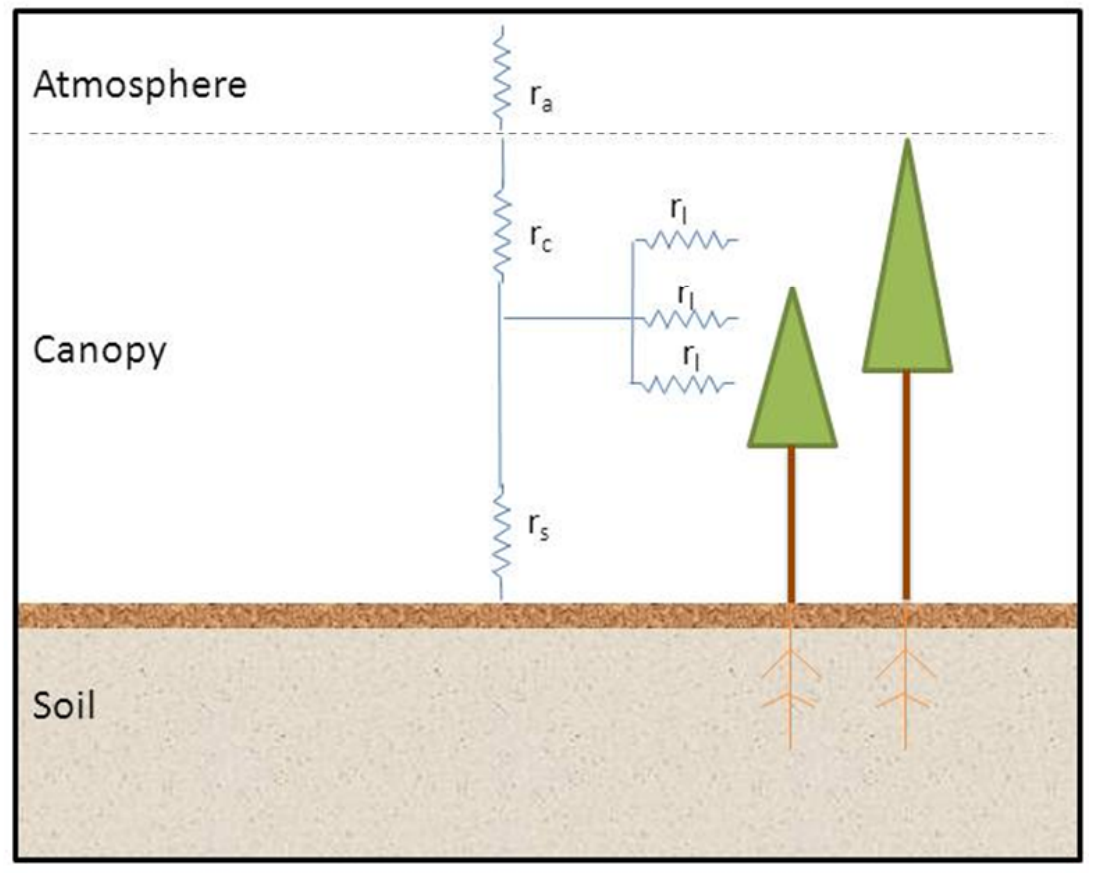

Figure 1. The network of resistances to HTO vapor transport in a forest.

Most of the time the soil resistance $\left(r_{s}\right)$ is so much larger than the other resistances, the flux of vapor from the soil can be ignored. In this case the deposition velocity can be evaluated by the equation.

$$
\mathrm{v}_{\mathrm{d}}=1 /\left(\mathrm{r}_{\mathrm{a}}+\mathrm{r}_{\mathrm{c}}+\mathrm{r}_{1} / \mathrm{LAI}\right)=1 /\left(\mathrm{r}_{\mathrm{a}}+\mathrm{r}_{\mathrm{c}}+1 /\left(\mathrm{LAI}^{*} \mathrm{~g}_{\mathrm{l}}\right)\right)
$$

where,

$\mathrm{v}_{\mathrm{d}}$ is the deposition velocity $(\mathrm{cm} / \mathrm{s})$

$r_{a}$ is the resistance from atmospheric diffusion in the boundary layer above the forest $(\mathrm{s} / \mathrm{cm})$

$\mathrm{r}_{\mathrm{c}}$ is the resistance from diffusion in air in the canopy $(\mathrm{s} / \mathrm{cm})$

$\mathrm{r}_{1}$ is the resistance for diffusion into the individual leaves $(\mathrm{s} / \mathrm{cm})$

LAI is the leaf area index and

$\mathrm{g}_{1}$ is the leaf conductance $(\mathrm{m} / \mathrm{s})$

During the winter leafless period, the flux from the vegetation approaches zero and the deposition velocity in a hardwood stand is the inverse of the soil resistance. 


\subsection{DEPOSITION VELOCITY}

\subsection{Vegetation}

\subsubsection{Deposition Velocity in Forests}

The deposition velocity of water for vegetated surfaces has been measured in several ways. Estimates have been made by measuring the vapor transport of water of the individual components of a stand of vegetation, primarily leaves and secondarily the soil beneath the vegetation. Deposition velocity has also been measured for whole stands using energy balance, eddy correlation, and sap flow methods.

Table 1 shows the range of leaf conductance measured for a variety of forest tree species. The conductance is measured in chambers by the rate of accumulation of water vapor in the chamber, or in the case of Murphy and Corey (1976) by accumulation of HTO in the vegetation. The measurements of Kelliher et al. (1995) are reported as the mean and standard deviation of the maximum conductance for a large number of studies. The other conductances shown are the range for forest species found at SRS. The range shown does not imply that the measurements were made under conditions that show the total range for a species but only the range for the environmental conditions under which the studies were done. For instance, many of the studies did not measure the conductance at night.

Table 1. Published measurements of leaf conductance for forest vegetation

\begin{tabular}{|l|c|c|c|l|}
\hline Vegetation Type & $\begin{array}{c}\text { Leaf } \\
\text { Conductance } \\
\mathbf{( c m / s )}\end{array}$ & $\begin{array}{c}\text { Estimated } \\
\text { Leaf Area } \\
\text { Index }\end{array}$ & $\begin{array}{c}\text { Estimated Stand } \\
\text { Deposition } \\
\text { Velocity } \mathbf{( c m / s )}\end{array}$ & \multicolumn{1}{|c|}{ References } \\
\hline Conifer forest & $0.57 \pm 0.24$ & 6.7 & $3.8 \pm 1.6$ & Kelliher et al. (1995) \\
\hline $\begin{array}{l}\text { Temperate } \\
\text { deciduous forest }\end{array}$ & $0.46 \pm 0.17$ & 5.1 & $2.3 \pm 0.9$ & Kelliher et al. (1995) \\
\hline Slash pine & $0.027-0.22$ & 8.7 & $0.2-1.9$ & Murphy and Corey (1976) \\
\hline Bald cypress & $0.15-0.27$ & 6.7 & $1.0-1.8$ & McLeod et al. (1986) \\
\hline Tupelo & $0.07-0.32$ & 5.1 & $0.4-1.6$ & McLeod et al. (1986) \\
\hline Black willow & $0.4-1.8$ & 5.1 & $2.0-9.2$ & McLeod et al. (1986) \\
\hline Button bush & $0.12-0.38$ & 5.1 & $0.6-1.9$ & McLeod et al. (1986) \\
\hline
\end{tabular}

As illustrated in Figure 2, the leaf resistances in the canopy are in a parallel network, and a rough estimate of the deposition velocity for the forest of a particular species can be made by multiplying the leaf conductance by the leaf area index, the leaf area per unit ground area. The deposition velocity estimated in this way does not include the contribution of turbulent diffusion through the canopy and the aerodynamic boundary layer above the forest. However, since the resistance associated with the leaf conductance is usually much greater than the resistance associated with the canopy and boundary layer, estimates of deposition velocity made on the basis of leaf conductance can be useful when other estimates are not available. The leaf area indices in the table are the 
mean values for forest stands of each species as compiled by Scurlock et al. (2001).

Table 2. Published measurements of forest deposition velocities

\begin{tabular}{|l|c|l|}
\hline Vegetation Type & $\begin{array}{c}\text { Stand deposition } \\
\text { velocity }(\mathbf{c m} / \mathbf{s})\end{array}$ & References \\
\hline Conifer forest & $2.12 \pm 0.71$ & Kelliher et al. (1995) \\
\hline Temperate deciduous forest & $2.07 \pm 0.65$ & Kelliher et al. (1995) \\
\hline Mixed deciduous forest & 0.22 & Baldocchi (1989) \\
\hline SRS pine plantations & $0.07-1.2$ & Murphy et al. (1981), Murphy (1985) \\
\hline Douglas-fir forest & $>1$ & Wharton et al. (2009) \\
\hline Pine plantation & $0.02-0.24$ & Ewers et al. (2001) \\
\hline Oak-grass savannah & $0.02-0.2$ & Baldocchi et al. (2004) \\
\hline Aspen-hazel forest & $0.0-2.8$ & Blanken et al. (1997) \\
\hline
\end{tabular}

Table 2 shows the range of deposition velocities found in experimental studies of forest stands. The values reported by Kelliher et al. (1995) are the maximum and standard deviation of maximum deposition velocity compiled for a number of experiments. The other deposition velocities are the ranges reported in the cited paper. The measurements were made by several methods. Many of the studies used the Bowen ratio approach where the measured net radiation less the measured heat flux to the ground is partitioned between convective heat transfer and latent heat transfer. In study of the SRS pine forest (Murphy et al. 1981, Murphy 1985), measurements of temperature and water vapor profiles were used to determine the ratio. In the other experiment in the pine forest (Ewers et al. 2001), sap flow measurements were used to determine evaporation. In the other four studies (Wharton et al. 2009, Baldocchi 1989, Baldocchi et al. 2004, Blanken et al. 1997), the net radiant energy less heat flux to the ground was partitioned using eddy correlation measurements of convective and latent heat. Measurement periods varied from daily averages (Baldocchi 1989, Ewers et al. 2001) to hour averages (Murphy et al. 1981, Murphy et al. 1985, Blanken et al. 1997).

The results summarized in the Table 1 and Table 2 indicate that deposition velocities approaching or exceeding $1.0 \mathrm{~cm} / \mathrm{s}$ are found in forest stand. As expected the deposition velocities estimated from the leaf conductance measurements are generally somewhat higher than those measure for entire forests.

\subsubsection{Calculation of Deposition Velocity in an SRS Pine Plantation}

While the meteorological conditions affect the value of deposition velocity, the dominant factor is the diffusion of water into or out of the leaves. The leaf surfaces are covered with a waxy coating to suppress evaporation. Small openings, stoma, in the leaf surface allow passage of gas between the atmosphere and the interior of the leaf.

The distribution of deposition velocity in a pine forest at SRS has been estimated from a model of canopy deposition velocities based on energy balance measurement taken in 
that stand (Murphy 1985, equation 14).

$$
\mathrm{v}_{\mathrm{d}}=\mathrm{v}_{\mathrm{dmin}}+\left(\mathrm{v}_{\mathrm{dmax}}-\mathrm{v}_{\mathrm{dmin}}\right)\left(0.01218 \mathrm{~T}+1.11 \mathrm{~S}-0.04374 \mathrm{~d}_{\mathrm{v}}\right)
$$

where,

$\mathrm{v}_{\mathrm{dmin}}$ is the minimum deposition velocity $(\mathrm{cm} / \mathrm{s})$

$\mathrm{v}_{\mathrm{dmax}}$ is the maximum deposition velocity $(\mathrm{cm} / \mathrm{s})$

$\mathrm{T}$ is temperature $\left({ }^{\circ} \mathrm{C}\right)$

$\mathrm{S}$ is solar radiation $\left(\mathrm{W} \mathrm{m}^{-3}\right)$ and

$\mathrm{d}_{\mathrm{v}}$ vapor density deficit, the difference between saturation density and actual vapor density based on relative humidity $\left(\mathrm{g} \mathrm{m}^{-3}\right)$.

In Murphy (1985) Equation 2 was developed using regression analysis of the experimentally derived deposition velocity and the simultaneous measurements of air temperature, solar radiation and vapor density deficit. During the regression analysis the values of $v_{d}$ were normalized by setting $v_{d i n}$ and $v_{d m a x}$ slightly below and slightly above the observed values. When Equation 2 is used to calculate the deposition velocity outside of the range of the original experiments, care must be taken to make sure the extrapolation does not predict unreasonable results. An example would be for night condition $(S=0)$ under a high vapor density deficit when the calculation might yield a negative deposition velocity.

In the calculation made in this report, value of $\mathrm{v}_{\mathrm{dmax}}$ was set as $1.2 \mathrm{~cm} / \mathrm{s}$ based on the maximum observed deposition velocity in the cited data. It is rare for the calculated values to reach the maximum. The value of $v_{d m i n}$ is more difficult to evaluate. The stand level measurements depend on measurement of either very small temperature and vapor gradients or small eddy fluxes. In either case the sensitivity of the measurement technique is limited at low deposition velocities. Studies done on individual pine leaves suggest that the minimum deposition velocity for whole stands is likely be less than $0.2 \mathrm{~cm} / \mathrm{s}$ (Table 1 , line 3) Since the value taken from leaf experiments is likely to overestimate the minimum deposition velocity for the stand, a value of $0.1 \mathrm{~cm} / \mathrm{s}$ was used in the calculations made for the pine plantation.

\subsubsection{Calculation of Deposition Velocity for SRS Forests Considering Hardwood Stands}

A complicating factor in using the deposition velocities derived from a pine stand to estimate the deposition velocity for use at SRS is the existence of a significant number of deciduous hardwood stands at SRS. Approximately $26 \%$ of the forested land is in hardwood forests and another 6\% in mixed hardwood pine stands (Parresol 2004). A model of hardwood stand response comparable to the pine stand data does not exist. However it is certain that the hardwood stands contain fewer leaves during the winter months (there are evergreen hardwood species in these stands). A rough correction for the hardwood component of the forest at SRS was made based on the relative area in each type of forest. It was assumed that the leafless period extended from the beginning of November to the end of March. The available data suggest that deposition velocity is 
very low in these stands during the winter but probably similar to that in the pine forest during the summer (Baldocchi et al. 2004). The deposition velocity for a leafless stand was set to $0.05 \mathrm{~cm} / \mathrm{s}$.

The calculations were performed using a continuous record of quality assured 15-minute values $(35,040$ observations per year) of temperature, relative humidity, and solar radiation collected at the SRS Central Climatology tower near $\mathrm{N}$-area during 2010. The temperature and humidity data were collected from instrumentation mounted at a height of 2-meters above ground. Solar radiation is measured nearby at ground level. The results are shown in Figure 2.

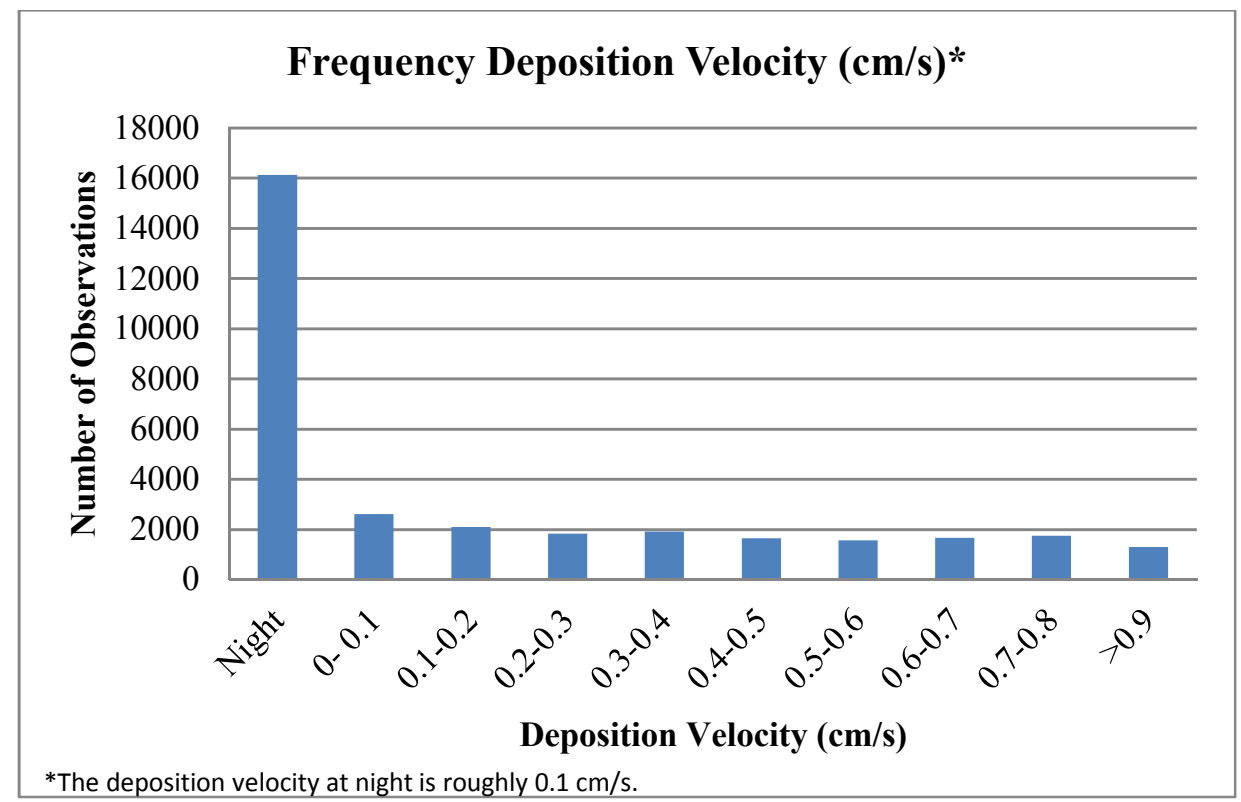

\section{Figure 2. The frequency distribution of deposition velocity predicted for $15-\mathrm{min}$ meteorology over a year.}

The average deposition velocity for the entire year is $0.27 \mathrm{~cm} / \mathrm{s}$. The average day time deposition velocity is $0.42 \mathrm{~cm} / \mathrm{s}$. The inclusion of the hardwood stands decreases the deposition velocities by $8 \%$. The relatively small influence of the loss of leaves by the hardwood stands is explained by the greater area in pine cover and the fact that half of the time the deposition velocity in both hardwood and pine stands is very low at night.

A better idea of how the deposition velocity in this forest is related to meteorological conditions affecting atmospheric dispersion is shown in Figure 3. The mean deposition velocity is plotted for the corresponding Pasquill-Gifford (PG) diffusion class over a single year. The determination of diffusion class was based on fifteen minute values of standard deviation in the vertical component of wind direction (sigma-elevation) following a method recommended by EPA (USEPA 2000). The sigma-elevation data were recorded at the 61-m level of the Central Climatology Tower.

It is clear that higher values of deposition velocity are associated with the Pasquill- 
Gifford stability classes that occur during sunny days (PG classes A and B) and the lower values are associated with stabilities that occur only at night (PG classes $\mathrm{E}$ and $\mathrm{F}$ ). The bars through the mean deposition velocity provide a measure of the range of deposition velocity around the mean for each stability class. The bars on the figure bracket $90 \%$ of the range of the calculated deposition velocities. Five percent of the values are equal to or less than the lower end of the bar and 5\% are equal to or greater than the upper end of the bar. It is clear that the lower bound of the D, E, and F stability class are determined by the lower bound set for the deposition velocity in equation 1 and the lower boundary set for leafless hardwood forest. The co-incidental relationship between deposition velocity and stability class is significant with respect to the conditions that produce a $95^{\text {th }}$ percent dose for the maximally exposed offsite individual (MOI).

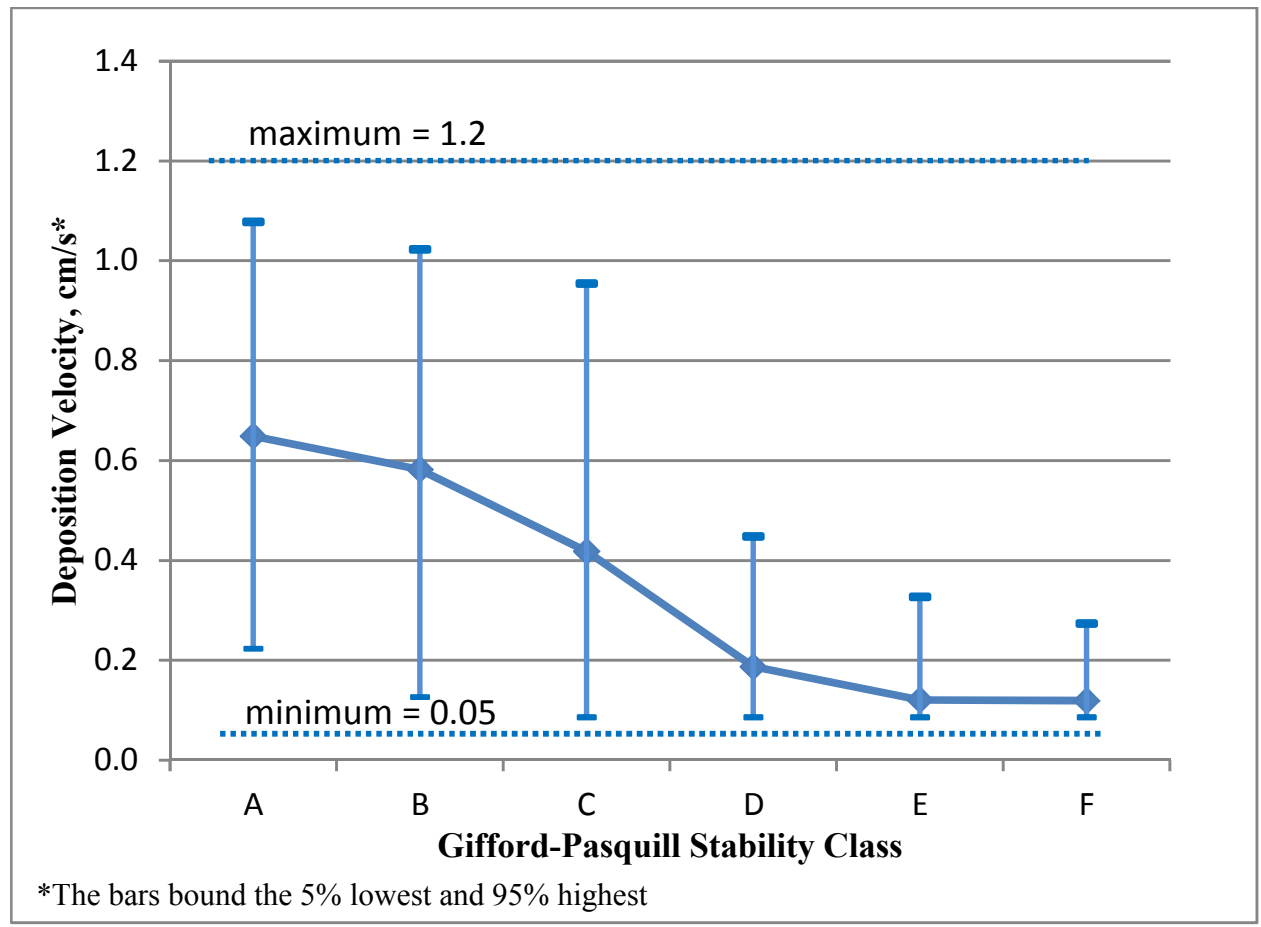

\section{Figure 3. Mean deposition velocity of SRS pine forest for Pasquill-Gifford stability classes.}

\section{$2.2 \quad$ Soil}

Water exchange between the atmosphere and soil in forests is expected to be much less than that between the atmosphere and the vegetation. This is based on consideration of two factors. The leaf surface area can be up to 10 times more per unit of ground surface area and the forest soil is covered (mulched) by a layer of litter derived from leaves and branches falling from the forest canopy. The best available estimate of soil deposition velocity in a forest is the deposition velocity for a leafless forest, probably less than 0.05 $\mathrm{cm} / \mathrm{s}$. This estimate might not apply to other vegetation types where different vegetation height and soil litter cover influence the exchange between the soil and the atmosphere. 


\subsection{RE-EMISSION AND RESIDENCE TIME}

\subsection{Vegetation}

The evaluation of the effects of HTO vapor deposition is complicated by the re-emission of tritium from the surface. Most of the HTO vapor diffusing into a stand of vegetation will dissolve in water in the leaves. Deposition will stop as equilibrium is reached between the concentration in the air and the concentration in the leaf. After plume passage, the HTO will diffuse back as vapor into the atmosphere. Assuming a constant wind direction as in MACCS2, this means that an MOI will be exposed to the re-emitted HTO vapor after exposure to the initial release. The total exposure will vary with the relationship between the MOI exposure period and the timing of the release and reemitted HTO vapor.

The timing of the re-emitted tritium exposure following the initial exposure from the release can be quantified in terms of the residence time of the HTO in the vegetation. The residence time is effectively the half-life of the tritium in the vegetation defined by:

$$
\mathrm{t}_{1 / 2}=-\left(\frac{\mathrm{V}}{\mathrm{A}}\right) * \frac{\ln (0.5)}{\mathrm{v}_{\mathrm{d}}}
$$

where V/A is the ratio of volume water in the leaf to the surface area of the leaves and $\mathrm{v}_{\mathrm{d}}$ is the deposition velocity of the leaves. This equation for stand residence time is analogous to the equation derived by Murphy and Corey (1976) for individual leaves. The ratio V/A has the units of length and is essentially the equivalent depth of water held in the leaves. Greater deposition velocity leads to shorter residence time. The faster HTO vapor enters the stand the faster it will leave the stand. More water in the vegetation leads to longer residence times. The greater the sink for HTO in the vegetation, the longer it takes for it to reach equilibrium.

Figure 4 shows the relationship between residence time and deposition velocity. For a forest with the characteristics of a pine plantation, a leaf area index of 8.7 was used in this calculation, based on the results of a compilation of forest data (Scurlock et al. 2001). An equivalent depth of water of pine leaf is around $0.008 \mathrm{~cm}$ (Murphy and Corey 1976, Hunt and Rock 1989). A similar calculation is made for mixed hardwood stands were the average leaf area index is 5.2 (Scurlock et al. 2001) and the average equivalent water content is close to $0.006 \mathrm{~cm}$ (Yilmaz et al. 2008). 


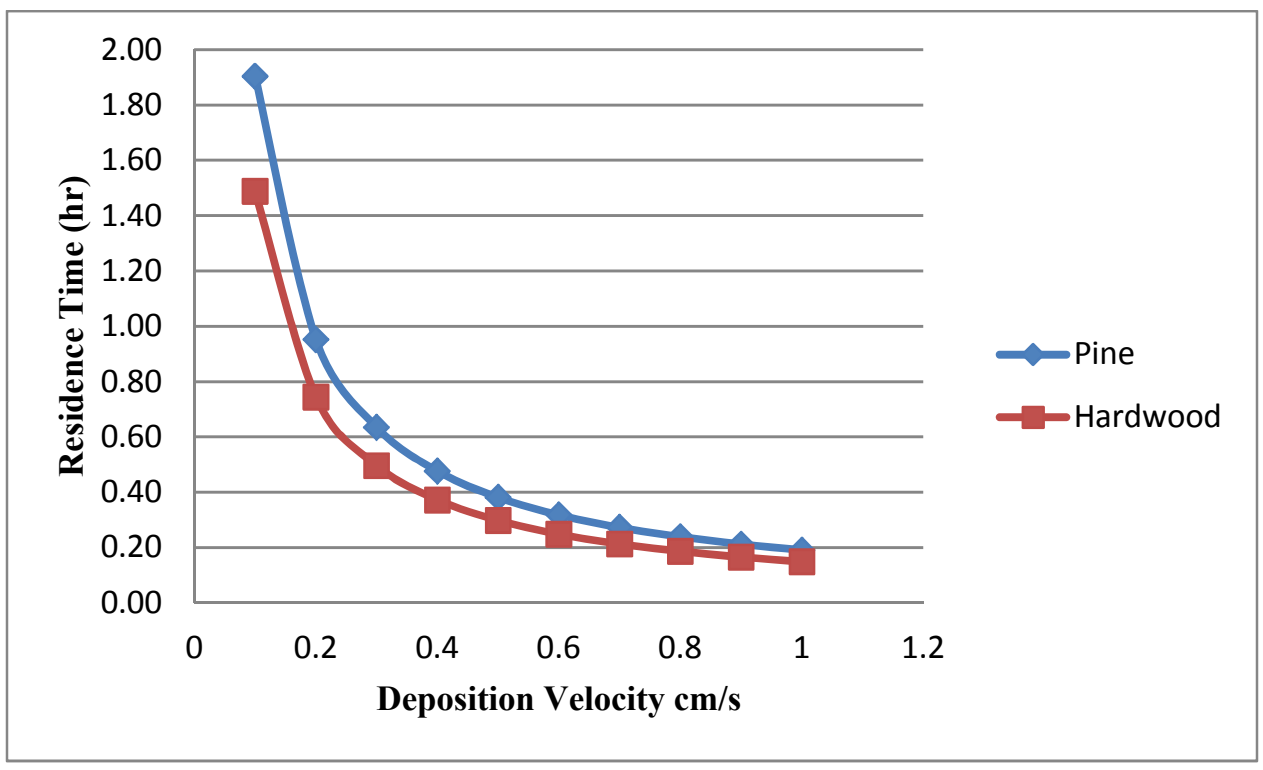

Figure 4. Relationship between residence time and deposition velocity calculated from the surface area and volume of leaf water from a typical pine plantation and mixed hardwood forest.

A few estimates are available from studies of tritium concentrations following releases or experimental exposures. Table 3 contains estimates of residence time for forest vegetation. The residence time for the SRS pine forest are estimated from the depletion curve in leaves following an accidental release of HTO. The residence time range for the pine leaf is an extrapolation of an experiment done on pine leaves to estimate the range of deposition velocities for a forest. The values of leaf area index and forest V/A are the same as used to calculate the values used in Figure 4.

The estimates for the pine plantation are calculated by equation 3 for $\mathrm{v}_{\mathrm{d}}$ of $0.1 \mathrm{~cm} / \mathrm{s}$ and $0.5 \mathrm{~cm} / \mathrm{s}$ and leaf area index and forest water content provided by Scurlock et al. (2001), Hunt and Rock (1989) and Yilmaz et al. (2008). The two estimates illustrate the inverse relationship between deposition velocity and residence time. The results based on measurements (lines 1 and 2) and calculations (lines 3 and 4) appear to agree reasonably well.

Table 3. Residence time (half-life) of HTO in the forest canopy

\begin{tabular}{|l|c|l|}
\hline \multicolumn{1}{|c|}{ Forest Type } & Residence Time (hr) & \multicolumn{1}{c|}{ Reference } \\
\hline SRS Pine Forest & 2.77 & Sweet et al. (1983) \\
\hline Pine Leaf & $1.4-3.2$ & Murphy and Corey (1976) \\
\hline Pine Plantation & 1.90 & Scurlock et al. (2001), Hunt and Rock (1989) \\
\hline Pine Plantation & 0.38 & Scurlock et al. (2001), Yilmaz et al. (2008) \\
\hline
\end{tabular}




\subsection{Soil}

Residence times in forest soils are expected to be longer than for vegetation, based on the lower deposition velocities and the greater potential water content of the soil. A few residence times are available from accidental and experimental exposures of forest soils. They are summarized in Table 4. In some cases the residence times are not reported in the papers but have been calculated from data on which the publication was based.

Table 4. $\quad$ Residence times for HTO in forest soils.

\begin{tabular}{|l|c|l|}
\hline & Residence Time (days) & \multicolumn{1}{c|}{ Reference } \\
\hline Mixed Tropical & 0.06 & Martin et al. (1970) \\
\hline Mixed Tropical & 2.5 & Martin et al. (1970) \\
\hline Mixed Tropical & 42 & Martin et al. (1970) \\
\hline Pine & 0.54 & Sweet et al. (1983) \\
\hline Pine & 1.32 & Sweet et al. (1983) \\
\hline Mixed Pine Hardwood & 6.40 & Murphy et al. (1977) \\
\hline
\end{tabular}

The shorter residence times are associated with vapor transport between the soil surface and atmosphere. The longer residence times are probably associated with uptake of water by tree roots, movement through the tree trunks, and eventual evapotranspiration from the trees. The long residence time suggest that soil deposition could have a significant effect on the timing of exposures from atmospheric releases. However, the low deposition velocities that are associated with long residence times suggest that the amount of HTO reaching the soil is small compared to the vegetation. This suggests that deposition to the soil is not an important factor when estimating deposition velocity for short term accidental releases. 
This Page Intentionally Left Blank 


\subsection{MODELING OF HTO DEPOSITION VELOCITY AND RE- MISSION IN SRS SAFETY ANALYSES}

\subsection{Deposition Velocity and Re-Emission Model}

In the previous sections the range of deposition velocities expected at SRS has been estimated. The deposition velocity is evaluated for different environmental conditions, which allows deposition velocity to be estimated for meteorological conditions which typically result in $95^{\text {th }}$ percentile MOI exposure.

The effect of re-emission of HTO on MOI exposure has been evaluated in terms of the reemission rate as controlled by the residence time of HTO in forest. The relationship between residence time and deposition velocity describes the response of the individual forest types found at SRS.

With this information, the effect and sensitivity re-emission can be evaluated for releases of HTO over SRS forests. A simple model of the atmospheric dispersion, deposition, and re-emission was created to simulate the interaction between these processes (Viner 2012).

The model uses a series of grid cells that represent surface concentrations within the area encompassed by the cell. Spacing between the grid cells is $300 \mathrm{~m}$. The release is modeled as a single Gaussian puff that moves over the grid cells following the mean wind. Diffusion of the puff as it moves downwind is defined according to analytical expression defined by the EPA methods (USEPA 1995) for determining $\sigma_{\mathrm{y}}$ and $\sigma_{\mathrm{z}}$ for any input stability class. Diffusion in the along wind direction was based on setting $\sigma_{\mathrm{x}}$ equal to $\sigma_{\mathrm{y}}$. The analytical functions are based on fitting the Pasquill-Gifford diffusion curves.

At each time step within the model, deposition to the grid cell under a puff is calculated as:

$$
\mathrm{D}=A * \mathrm{C}_{\mathrm{a} 0} * \mathrm{v}_{\mathrm{d}} * \Delta \mathrm{t}
$$

where D is the amount of HTO deposited per area of grid cell, A is the area of the grid cell, $\mathrm{C}_{\mathrm{a} 0}$ is the atmospheric concentration of HTO over the grid cell and $\Delta \mathrm{t}$ is the timestep of the model.

The prediction of re-emission from a grid cell is performed similarly to the prediction of deposition, using the same residence time constant which incorporates the characteristics of the SRS forest

$$
\mathrm{R}=\mathrm{V} * \mathrm{C}_{\mathrm{s}} *\left(1-\mathrm{e}^{-\Delta \mathrm{t} / \tau}\right)
$$

where $\mathrm{R}$ is the amount of HTO re-emitted per unit of grid cell, V is the volume of a grid cell, $\mathrm{C}_{\mathrm{s}}$ is the surface concentration in the grid cell, $\mathrm{V}$ is the volume of plant material that can store and re-emit HTO and $\tau$ is the residence time constant used to consistent with deposition velocity as defined in Equation 3. The volume of plant material was assumed 
to be uniform across a grid cell with an effective depth of $1 \mathrm{~m}$, resulting in a volume equal to the area of a grid cell. The deposition and re-emission procedures are applied to each grid cell within the model.

Under the conditions imposed by this calculation, there will be a net increase in HTO concentration of the grid cell if deposition is greater than surface re-emission, no net transfer if the deposition is equal to the re-emission, and net a decrease in surface grid cell concentration if deposition is less than the re-emission. The atmospheric concentration of HTO at any time over a grid cell is calculated using a mass-balance equation of:

$$
\mathrm{Ca}=\left(\Delta \mathrm{HTO}_{\mathrm{a}}+\mathrm{R}-\mathrm{D}\right) / \mathrm{V}_{\mathrm{g}}
$$

where $\triangle \mathrm{HTO}_{\mathrm{a}}$ is the net change in HTO over the grid cell due to advection with the wind and $\mathrm{V}_{\mathrm{g}}$ is the volume of air above the grid cell.

When HTO is re-emitted from the surface, an additional puff is created over the grid cell that released the HTO which is then dispersed downwind. Additional puffs are also created when any puff exceeds the size of a single grid cell to represent the horizontal diffusion of HTO. Checks are performed within the model to ensure the sum of all HTO stored in puffs and at the surface equal the initial release.

The results of these calculations are shown in Figure 5 for meteorological conditions typical of $95^{\text {th }}$ percentile exposure to an MOI at the SRS boundary (night time, $\mathrm{v}_{\mathrm{d}}=0.1, \tau$ $=2 \mathrm{hr}$, Pasquill-Giffords Stability Class F, wind speed $=100 \mathrm{~m} / \mathrm{s}$ ). The figure illustrates the position of the puff two hours after the plume has originally reached the SRS boundary ( $3.25 \mathrm{hr}$ after release). It shows that $99.83 \%$ of the release has passed the MOI.

Figure 5 illustrates the result of a simulation. The air concentrations at a time two hours after the passage of the plume from the SRS boundary shows that most of the HTO, both from the original puff passage and from the re-emission from the vegetation, has passed the SRS boundary. 

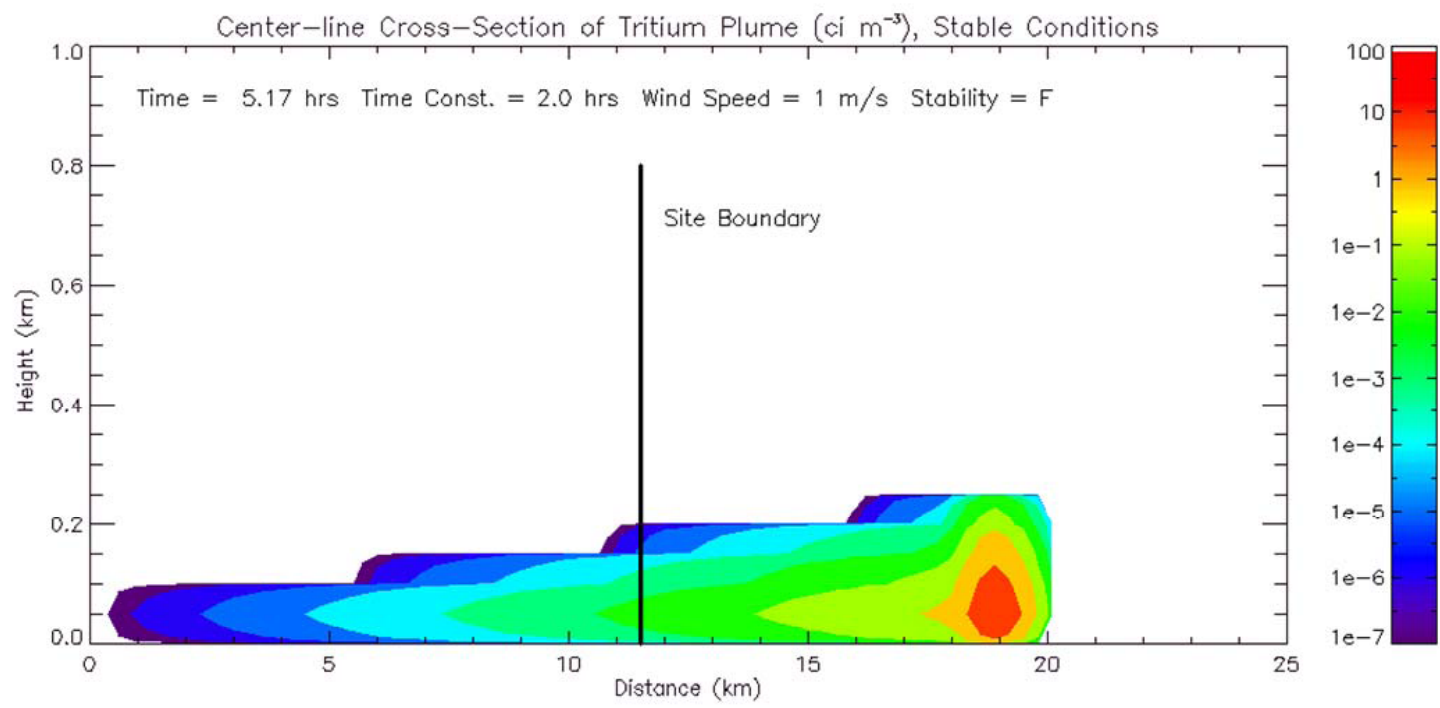

Figure 5. A cross-section along the center-line of the HTO cloud two hours after first reaching the site boundary (labeled; $\sim 11.5 \mathrm{~km}$ )

Note: The magnitude of concentration decreases rapidly behind the initial puff which is located at the right. The wind is blowing from left to right in this figure.

Table 5 shows the percent of the release impacting the MOI at the plant boundary for three release scenarios with varying deposition velocity: $0.0 \mathrm{~cm} / \mathrm{s}$ (no deposition; $\tau=\infty$ ), $0.1 \mathrm{~cm} / \mathrm{s}$ (estimated bounding value for MOI exposure; $\tau=2 \mathrm{hr}$ ) and $0.5(\tau=0.4 \mathrm{hr}) \mathrm{cm} / \mathrm{s}$. The residence times used in the calculations for each deposition velocity correspond to those predicted by Equation 3. The MOI exposure is reduced by as much as $41.5 \%$ by deposition when re-emission is not taken into account. The maximum reduction in exposure is only $0.3 \%$ when re-emission is calculated. Note that in the 24 -hr re-emission column, the values for 0.1 and $0.5 \mathrm{~cm} / \mathrm{s}$ are not theoretically equal to $100 \%$ since a very small amount of HTO will remain in the vegetation for an infinite amount of time. However, this amount is many orders of magnitude less than the original release and is considered negligible.

Table 5. The percent of a puff release of HTO that passes the site boundary ( $\sim 11.5 \mathrm{~km})$ within 2 hours of first reaching it

\begin{tabular}{|c|c|c|c|}
\hline \multirow{2}{*}{ Deposition Velocity $\mathbf{( c m} / \mathbf{s})$} & \multirow{2}{*}{ No Re-emission } & 2-hr & 24-hr \\
\cline { 3 - 4 } & $100.00 \%$ & $100.00 \%$ & $100.00 \%$ \\
\hline 0.0 & $93.33 \%$ & $99.96 \%$ & $100.00 \%$ \\
\hline 0.1 & $70.89 \%$ & $99.70 \%$ & $100.00 \%$ \\
\hline 0.5 & \multicolumn{2}{|c}{$\%$} \\
\hline
\end{tabular}

Table 6 shows the same scenarios as table 5 but calculated at a distance of 100 meters from the release point using a grid spacing of $20 \mathrm{~m}$ and time step of $10 \mathrm{~s}$. The effect of deposition velocity on the calculation is extremely small. The effect of deposition velocity on the calculation is extremely small. 
Table 6. The percent of a puff release of HTO at $\mathbf{1 0 0}$ meters downwind of the release point within 2 hours of first reach that distance.

\begin{tabular}{|c|c|c|}
\hline Deposition Velocity & No Re-emission & With Re-emission \\
\hline $\mathbf{0 . 0}$ & 100 & 100 \\
\hline $\mathbf{0 . 1}$ & $99.94 \%$ & $99.95 \%$ \\
\hline $\mathbf{0 . 5}$ & $99.70 \%$ & $99.99 \%$ \\
\hline
\end{tabular}

\subsection{Potential Impacts to the MOI}

The DNFSB letter not only questions the local, scientifically justifiable value of deposition velocity at SRS but also the dose to the MOI using this value in the MACCS2 code. The effect of using the $0.0 \mathrm{~cm} / \mathrm{s}$ deposition velocity recommended here rather than the default $0.5 \mathrm{~cm} / \mathrm{s}$ historically used in MACCS2 at SRS increases the dose to the MOI at the site boundary $(11.5 \mathrm{~km}$ ) by $17 \%$ (Hope 2012 ). Likewise, the effect of using a 0.1 $\mathrm{cm} / \mathrm{s}$ deposition velocity increases that dose only by $13 \%$. Because MACCS2 does not model re-emission, it is more realistic to use the effective deposition velocity of $0.0 \mathrm{~cm} / \mathrm{s}$.

The effect of the dose at 100 meter downwind would be expected to be small since the plume has not passed over much forest. Actually, the area near the release point is paved parking lot and deposition to the forest is not even possible. As expected, the effect of the value of deposition velocity used in the code is very small, an increase of dose of $1 \%$ when the $0.0 \mathrm{~cm} / \mathrm{s}$ deposition velocity is used rather than the $0.5 \mathrm{~cm} / \mathrm{s}$ historically used in MACCS2 at SRS (Hope 2012). 


\subsection{CONCLUSIONS}

Daylight HTO deposition velocities in forest vegetation can range from 0.07 to more than $2.8 \mathrm{~cm} / \mathrm{s}$. The average deposition velocity during daylight periods for an SRS pine plantation is around $0.42 \mathrm{~cm} / \mathrm{s}$. Night deposition velocities are lower. The minimum deposition velocity is likely to be around $0.1 \mathrm{~cm} / \mathrm{s}$.

Deposition velocity and residence time (half-life) of HTO are related by the leaf area and leaf water volume in the forest. For the characteristics of the pine plantation at SRS the daylight average residence time is 0.4 hours and the night residence time is around 2 hours.

The simulations made with a simple model of atmospheric dispersion, deposition and reemission of HTO vapor suggest that, deposition velocity is about $0.1 \mathrm{~cm} / \mathrm{s}$ for meteorological conditions defining the $95^{\text {th }}$ percentile maximum exposure, the net effect of deposition is very small because of the re-emission following the initial exposure. Therefore, an effective deposition velocity of $0.0 \mathrm{~cm} / \mathrm{s}$ is appropriate for safety analysis with the MACCS2 code because the model does address HTO re-emission. 
This Page Intentionally Left Blank 


\subsection{REFERENCES}

Baldocchi, D. D. 1989. Turbulent transfer in a deciduous forest, Tree Physiology 5: 357377.

Baldocchi, D. D., L. Xua and N. Kiang 2004. How plant functional-type, weather, seasonal drought, and soil physical properties alter water and energy fluxes of an oak-grass savanna and an annual grassland Agricultural and Forest Meteorology 123: 13-39.

Blanken, P. D., T. A. Black. P. C. Yang, H. H. Neumann, Z. Nesic, R. Staebler, G. den Hartog, M. D. Novak and X. Lee 1997. Energy balance and canopy conductance of a boreal aspen forest: Partitioning overstory and understory components. J. Geophysical Research 102 (D24): 28,915-28,927.

Chanin, D. I. and M. L. Young 1998 Code Manual for MACCS2: Volume 1, User's Guide: NUREG/CR-6613/SAND97-0594, Sandia National Laboratories, U.S. Nuclear Regulatory Commission, Washington DC.

Defense Nuclear Facilities Safety Board (DNFSB) 2011. National Nuclear Security Administration, August 19, 2011. Letter, from Winokur to D'Agostino, Defense Nuclear Safety Board Safety Basis Development Issues with the Tritium Facilities at the Savannah River Site.

Ewers, B. E., R. Oren, N. Phillips, M. Stromgren and S. Linder 2001. Mean canopy stomatal conductance responses to water and nutrient availabilities in Picea abies and Pinus taeda. Tree Physiology 21: 841-850.

Hope, E. P. 2012, "Results for MACCS2 Assessment of Tritium Oxide Release" S-ESRG-00019 Revision 0.

Hunt, E. R. and B. N. Rock 1989. Detection of changes in leaf water content using nearand middle-infrared reflectances. Remote Sensing of Environment 30:43-54.

Kelliher, F. M., R. Leuning, M. R. Raupach and E.-D. Schulze 1995. Maximum conductances for evaporation from global vegetation types. Agric. For. Meteorol. 73: $1-16$.

Martin, J. R., C. F. Jordan, J. J. Koranda, and J. R. Klaine 1970. Radiocological Studies of Tritium Movement in a Tropical Rain Forest, UCRL-72256, 20 pp.

McLeod, K. W., L. A. Donovan, N. J. Stumpff, and K. C. Sherrod. 1986. Biomass, photosynthesis and water use efficiency of woody swamp species subjected to flooding and elevated water temperature. Tree Physiology 2:341-346. 
Murphy, C. E. Jr. 1985. Carbon dioxide exchange and growth of a pine plantation. Forest Ecology and Management 11: 203-224.

Murphy, C. E. Jr. and J. C. Corey 1976. Absorption of HTO vapor from the atmosphere by the needles of pine trees. Eco. Soc. Amer. Special Publication 1, Radioecology and Energy Resources. Ed. C. Cushing. 108-112.

Murphy C. E. Jr., J. F. Schubert and A. H. Dexter 1981. The energy and mass exchange characteristics of a loblolly pine plantation. Journal of Applied Ecology 18: 271281.

Murphy, C. E. Jr., J. R. Watts and J. C. Corey 1977. Environmental tritium transport from atmospheric releases of molecular tritium. Health Physics 33:3 25-331.

Parresol, B. R. 2004. Point and Fixed Plot Sampling Inventory Estimates at the Savannah River Site, South Carolina, Report to the US Forest Service Savannah River February, 2004.

Sinclair, T. R., C. E. Murphy Jr, and K. R. Knoerr 1976. Development and evaluation of simplified models for simulating canopy photosynthesis and transpiration. Journal of Applied Ecology 13: 813-829.

Sweet, C. W., C. E. Murphy, and R. Lorenz 1983. Environmental tritium transport from and atmospheric release of HTO. Health Physics 44: 13-18.

Scurlock, J. M. O., G. P. Asner, and S. T. Gower 2001. Worldwide Estimates of Leaf Area Index, 1932-2000. ORNL/TM-2001/268. Data set available at http://www.daac.ornl.gov. Oak Ridge National Laboratory Oak Ridge, Tennessee.

U. S. Environmental Protection Agency (EPA) 1995. User's Guide for the Industrial Source Complex (ISC3) Dispersion Models. Volume II - Description of Model Algorithms, EPA-454/B-95-003b, Office of Air Quality Planning and Standards, Research Triangle Park, NC.

U. S. Environmental Protection Agency (EPA) 2000. Meteorological Monitoring Guidance for Regulatory Modeling Applications, EPA-454/R-99-005, Office of Air Quality Planning and Standards, Research Triangle Park, NC.

Viner, B. J. 2012. Modeling Tritium Transport, Deposition and Re-emission, SRNL-STI2012-00131.

Wharton, S., M. Schroeder, K. Bible, M. Falk, T. P. U. Kyaw 2009. Stand-level gasexchange responses to seasonal drought in very young versus old Douglas-fir forests of the Pacific Northwest, USA. Tree Physiology 29: 959-974. 
Yilmaz, M. T., E. R. Hunt and T. J. Jackson 2008. Remote sensing of vegetation water content from equivalent water thickness using satellite imagery. Remote Sensing of Environment 112: 2514-2522. 
This Page Intentionally Left Blank 
SRNL-STI-2012-00128, Rev. 0

April 3, 2012

Recommended HTO Deposition Velocity for Use in SRS Safety Analyses 


\section{$\underline{\text { Tritium Programs }}$}

Debra K. Utley

Donald W. Bickley

Marlene L. Moore

\section{N\&CSE}

John C. Grove

Lawrence E. Johnson

Andrew M. Vincent

Bonnie J. Shapiro

Jon C. Guy

Eric P. Hope

Scott K. Elliott

$\underline{\text { NNSA }}$

Timothy M. Smith

$\underline{\text { SRNL }}$

David E. Eyler

John E. Marra

Anthony E. Burris

Mary K. Harris

Alice M Murray

Lori M. Chandler

Stephen J. Hensel

Charles H. Hunter

Jack J. Mayer

Patricia L. Lee

G. Timothy Jannik

Charles E. Murphy

Brian J. Viner
Chief Engineer, Tritium Programs

Deputy Chief Engineer, Tritium Programs

Tritium Engineering

Site Chief Engineer

Manager, N\&CSE

N\&CSE Safety Programs

Manager, N\&CSE SRNL and Tritium Support

N\&CSE SRNL and Tritium Support

N\&CSE Analytical Support

Manager, N\&CSE Analytical Support

AM for Mission Assurance

Deputy Laboratory Director, SRNL

Associate Laboratory Director, Science and Technology

Associate Laboratory Director, National Security

Director, Computational Sciences

Acting Director, Environmental Sciences and

Biotechnology

Manager, Nonpoliferation Technology

Manager, Computational Engineering and Sciences

Manager, Atmospheric Technologies

Manager, Environmental Sciences

Manager, Applied Computational Engineering and

Statistics

Environmental Sciences

Environmental Sciences

Atmospheric Technologies 